\title{
RESIDENTS' OPINIONS ON THE VALUE OF STREET TREES DEPENDING ON TREE LOCATION
}

\section{By James Gorman}

\begin{abstract}
This research sought to determine whether there was a difference of opinion on the value of street trees among urban residents depending on whether residents had a street tree planted directly in front of their house. In response to a structured questionnaire, 676 residents of State College, Pennsylvania, U.S., gave their opinions of benefits and annoyances of street trees. Demographic findings utilized descriptive statistics to list the characteristics of the target population. This research showed that there was a statistically significant difference in residents' opinions depending on whether there was a street tree planted in front of their residence. In developing public policies related to street trees, it is recommended that further similar studies be conducted for better understanding of residents' opinions on this issue.

Key Words. Street trees; residents' opinions and perceptions.
\end{abstract}

Prior research has documented opinions and attitudes regarding the values of trees. Studies have been conducted that focused on people's attitudes toward specific kinds of trees (Sommer et al. 1990; Schroeder and Ruffolo 1996) and residents' attitudes and behavior regarding tree planting and care (Summit and McPherson 1998). Perceived economic benefits (Daily 1997), social benefits (Coley et al. 1997), symbolic importance (Smardon 1988), and psychological value (Ulrich 1984; Hull 1992) have been researched and effectively documented. This research sought to determine if there is a difference in State College, Pennsylvania, U.S., residents' opinions regarding street trees depending on whether street trees were located directly in front of residents' homes

\section{MATERIALS AND METHODS State College, Pennsylvania}

State College Borough is located in the Nittany Valley of central Pennsylvania, being almost equidistant from the cities of Philadelphia and Pittsburgh. The borough, incorporated in 1896, currently occupies an area of 128 ha (316 ac), and has a general elevation of $300 \mathrm{~m}$ (984 ft) above sea level. State College Borough is in the center of a larger United States Census Metropolitan Statistical Area (MSA), the Centre Region MSA, which includes five surrounding townships. State College Borough currently is, and historically has been, the most populous entity of the region and included 38,981 residents in the 1990 United States Census (U.S. Department of Commerce 1990).
The main part of the Pennsylvania State University campus lies on 25 ha (62 ac), or 19\% of the total land area of State College Borough. The university is a driving economic force and predominant employer in both State College Borough and the region. Other major components of the economy include high-technology industries, tourism, and light manufacturing. During the early decades of the past century, State College's total population had often been nearly 50\% students. The 1990 United States Census identified 11,339 individuals as permanent full-time residents of State College Borough (U.S. Department of Commerce 1990). These people represented the targeted study population to be used for the questionnaire survey of this research.

\section{State College Borough Street Trees}

A complete street tree inventory prepared by the borough arborist with technical assistance from Pennsylvania State University's School of Forestry Resources was compiled in 1977. The inventory identified more than 5,300 street trees of 57 different species or varieties. Another inventory, conducted in 1991, indicated an increase of about 700 trees over the 1977 number (State College Borough Municipal Tree Plan 1993-1998.) In 1984, State College received designation from The National Arbor Day Foundation as a Tree City USA, an indication of the community's commitment to manage their urban forest resource. In 1990, the borough purchased a computerized inventory program called "Tree Manager," developed by ACRT, Inc. Information about all street trees has since been stored and accessed by computer.

\section{Methodology}

The methodology was to deliver a survey questionnaire to two groups of respondents selected from this community's population. Residents with street trees planted directly in front of their homes, identified from an up-to-date street tree inventory, were tracked separately from respondents without street trees planted directly in front of their homes, thus increasing the validity of obtaining opinions from residents that had street trees planted directly in front of their homes. From the identified address base of residents with a street tree planted directly in front of their homes, survey questionnaires were mailed in a random method, 
securing the first data group. Using the remaining town addresses, an additional mailing was randomly selected to seek out the desired second group, residents without street trees directly in front of their homes.

\section{Procedures}

By utilizing one aspect of the Tree Manager program, all inventoried street trees were located relative to a street address. Each address was further defined using a rectangular grid template pattern containing 24 numbered positions or "cells" surrounding said address. Seven cells were located along the front of each address, seven cells were located at the rear, and five cells were on either of two sides. Accordingly, it was possible to search for and print a list of trees found only in cells numbered one through seven, or trees located directly in front of residences.

From all the trees found directly in front of residences, a working list was composed of the ten predominant species of street trees planted in State College. These ten tree species listed in descending order are sugar maple (Acer saccharum), red oak (Quercus rubra), red maple (Acer rubrum), Norway maple (Acer platanoides), pin oak (Quercus palustris), green ash (Fraxinus pennsylvanica), littleleaf linden (Tilia cordata), tulip poplar (Liriodendron tulipifera), honeylocust (Gleditsia triacanthos), and American elm (Ulmus americana). Trees that had a diameter at breast height (dbh) of less than $15 \mathrm{~cm}$ (6 in.) were not included in this research, primarily to control for those residents not yet having experienced a full-year cycle with a tree planted in front of their residence and to allow for possible incomplete data input of most recent plantings. It was discovered that some addresses had more than one tree planted directly in front of them on this listing. The list was prepared to note each street address rather than each tree. In a random selection method, 977 addresses were selected to receive survey questionnaires. Surveys sent to these addresses were printed on colored paper that would later identify respondents known to have trees planted directly in front of their residences. Each survey was accompanied by a cover letter and a postage-paid, addressed return envelope. It was believed that a higher respondent rate of return would be achieved if the questionnaires were addressed to individuals rather than sent to "Current Resident" at each address. Accordingly, commercial mailing labels of residents of State College were purchased for this purpose. Using United States Postal Service ZIP code information, all addresses within Pennsylvania State University property were intentionally excluded with a goal of surveying only off-campus, permanent full-time residents. From the remaining mailing labels, 1,023 addresses were randomly selected in an effort to obtain questionnaire responses from individuals without a tree planted directly in front of their residence. Identical survey questionnaires printed on white paper were mailed, along with identical cover letters and stamped return envelopes, to these people. Sommer et al. (1990) suggests that the return rate for this kind of survey is $20 \%$ to $25 \%$, if no follow-up post cards are used or telephone calls made.

\section{Questionnaire Design}

Using a questionnaire modeled after those developed earlier by Sommer et al. (1990) and DeAraujo (1994), participants were asked to respond regarding the street trees growing directly in front of their residence or along the street on which they live. The questionnaire included a list of 11 possible positive features (benefits) and 11 possible negative features (annoyances) of street trees. Using simple checkmarks, benefits were to be rated: no benefit, little benefit, moderate benefit, or great benefit. Annoyances were determined using a similar rating scale. Respondents were also asked for their opinions concerning how important street trees are in State College: of great importance, of moderate importance, not important, or no opinion. "Yes" and "no" questions were used to gauge respondents' willingness to volunteer to help maintain any street trees along the street on which they live and their willingness to contribute money toward a fund used to care for street trees within State College. One question asked whether there was a street tree planted directly in front of their residence. An answer of "yes" to this question was followed by questions regarding respondents' satisfaction with the kind of tree planted and the level of maintenance/care provided to the tree.

Demographic information regarding age, gender, education, race, length of residence, and type of residence were included at the end of this survey questionnaire. The questionnaire was printed on both sides of two 8.5- by 11inch sheets of paper, folded letter-style. The questionnaire was mailed with a one-sheet cover letter, printed on both sides, providing illustrated definitions of street trees as criteria of the research.

\section{Data Analysis}

The Statistical Package for Social Sciences (SPSS) was used to compile and analyze the data (Fischer 1996; Voelkl and Gerber 1999). Prior to data entry of responses to questions included in this survey, a codebook was created. This codebook identified the primary variable of each question by using a name limited to eight characters, for example "gender," or "age". A short statement clarifying the label (the meaning) of each possible variable name (e.g., male or female) was accompanied by a numerical code for each answer. For example, $1=$ male, $2=$ female, and $0=$ missing answer or blank.

Data were analyzed using t-test and chi-square methods to determine if there was a statistically significant difference between the means reported from the two subgroups- 
those with and those without street trees planted directly in front of their residences. The respondents' answers on these factors were measured on a three-point scale, with $3=$ great benefit, $2=$ moderate benefit, $1=$ little benefit, and $0=$ no benefit or does not apply. The frequencies for each positive and negative factor were then calculated to provide an overall mean rating.

\section{RESULTS}

\section{Survey Responses}

The total sample consisted of 2,000 questionnaires mailed to residential addresses, of which 104, or approximately 5\%, were undeliverable because of the resident's death or relocation from the address. The total of 676 returned and answered questionnaires from the 1,896 delivered equaled a $36 \%$ rate of response. This total sample was divided into two subgroups: 568 respondents (84\%) who had a tree planted directly in front of their residences and 108 respondents $(16 \%)$ who did not have a tree directly in front of their residences. It should be noted that 90 of the 568 respondents (or 16\%) who had a tree planted in front were not from the original identified tree in front list. These 90 people likely had a tree in front of their homes that was less than $15 \mathrm{~cm}$ (6 in.) dbh or had trees other than the aforementioned top ten planted tree species in State College.

\section{Demographics}

Gender composition of the 676 respondents was 52.5\% female and $47.5 \%$ male. The age range of respondents was likewise well distributed. The education of respondents reflects the long heritage of State College's association with Pennsylvania State University. Of the total respondents, 85\% reported having at least a college degree; $6 \%$ reported achieving a business or trade school level of education, and $8 \%$ attained a high school level of education. A clear majority of respondents, $84.8 \%$, lived in a house, $10 \%$ lived in an apartment, and 3\% lived in a condominium. Regarding length of occupancy of current residence, 53\% had lived longer than 10 years at their address. Another 22\% reported living 4 to 10 years at their current address. An additional 20\% reported living 1 to 3 years at the present residence (Table $1^{*}$ ).

\section{Data Results}

The t-test evaluation analysis of positive features of street trees found statistical significance in 5 of the 11 factors included on the questionnaire. These factors were give shade ( $\mathrm{t}$-value $=3.105, \mathrm{p}=.002)$; pleasing to the eye ( $\mathrm{t}$-value $=$ $2.126, \mathrm{p}=.036)$; flowers on tree $(\mathrm{t}$-value $=-4.274, \mathrm{p}=.000)$; neighborhood more livable ( $\mathrm{t}$-value $=2.723, \mathrm{p}=.007)$; and increase property value $(\mathrm{t}-\mathrm{value}=3.136, \mathrm{p}=.002)($ Table 2$)$.

The analysis of negative features of street trees found statistical significance in 3 of the 11 factors on the question- naire: branches break power lines in storms (t-value $=$ $-2.112, \mathrm{p}=.037)$; sidewalk damage $(\mathrm{t}$-value $=2.506, \mathrm{p}=$ .012 ); and trees block visibility ( $\mathrm{t}$-value $=-3.209, \mathrm{p}=.002)$ (Table 3).

Support for street trees within State College appears exceedingly strong: A total of $91.7 \%$ of all respondents classified street trees in State College as being of great benefit. Of those respondents with street trees directly in front of homes, 92.8\% stated street trees were of great importance. Of respondents without a street tree in front of their homes, $85.8 \%$ gave the same answer. The observed relationship between the two groupings was statistically significant at the .05 level (chi-square $=10.000, \mathrm{df}=2$, significance $=.007)($ Table 4$)$.

Of all respondents, $61.6 \%$ reported that they would be willing to volunteer to help maintain street trees along their street. Of respondents with street trees directly in front of houses, $62.3 \%$ stated a willingness to volunteer to help maintain street trees. Of respondents without a street tree in front of their houses, $57.8 \%$ reported being willing to volunteer to maintain street trees. The observed relationship between the two groupings (tree vs. no tree) for this question was not statistically significant (chi-square $=.707$, $\mathrm{df}=1$, significance $=.401)($ Table 5$)$.

Thirty-six percent of total respondents stated a willingness to contribute money toward a dedicated fund used solely for the care of street trees. Of respondents with street trees directly in front of homes, $37 \%$ stated a willingness to contribute money to care for street trees. Of respondents without a street tree in front of their houses, 33.3\% reported a willingness to contribute money for the care of street trees. The observed relationship between the two groupings (tree vs. no tree) for this question was not statistically significant (chi-square $=7.625, \mathrm{df}=3$, significance $=.054)($ Table 6).

Additional findings of related interest indicated that of respondents with trees planted directly in front of their residences, 90\% were satisfied with the level of maintenance/care that the street tree received. Of these same respondents, $84 \%$ were pleased with the kind of tree planted in front of their homes. Thirty-seven percent reported giving care themselves or paying to have care given to the street tree planted directly in front of their home.

\section{DISCUSSION}

Several factors might have led to these exceedingly strong positive responses regarding street trees, which may not be replicable among other urban communities. The fact that State College has long been home to a major successful university may result in a higher level of education among off-campus permanent residents. With $85 \%$ of respondents reporting at least a college degree, it could be argued that this research was a beneficiary of insightful, educated responses to the survey questionnaires. Also, State College 
has in place an active street tree program that perhaps has enhanced the general positive opinions regarding street trees. In addition, the cover letter for this questionnaire was on Longwood Graduate Program letterhead, and Longwood Gardens is frequently associated in people's minds with sylvan beauty. Nonetheless, this research provides new knowledge regarding the topic of urban residents' opinions on the value of street trees.

Seeking to determine whether urban residents' opinions would be impacted depending on whether there is a street tree planted directly in front of their residences, the data presented would seem to partially confirm this. The three negative features with statistically significant differences (branches break power lines, sidewalks are damaged, and trees block visibility) have in common the issue of public safety. Respondents without trees in front of their homes expressed a higher level of annoyance with branches breaking power lines. This finding may be in part due more to media headlines than to real experience or perhaps from having suffered the inconvenience of lost power due to tree conflicts without having any of the direct benefits of a tree planted in front of their houses. Alternately, respondents with trees in front expressed a higher level of annoyance with damaged sidewalks. Homeowners, who have a fiscal obligation for sidewalk repairs in front of their homes, or who are weary of dealing with trip hazards, might explain this difference of opinions.

Four of the five positive features reported to have statistically significant differences (give shade, pleasing to the eye, flowers on tree, and neighborhood more livable) have aesthetic characteristics. The fifth positive feature, increase property value, has an economic characteristic. Self-interest suggests an explanation for the statistically significant differences of the benefits of increasing property value, giving shade, and being pleasing to the eye, which all received higher mean ratings by respondents with trees in front of homes than by those without trees in front of their homes. Actual experience may explain why the feature "flowers on tree" had a much lower mean rating from respondents with trees in front of their homes, as nine of the top ten planted tree species in State College have inconspicuous flowers.

Findings from this study may be instructive also for those features that showed no statistically significant differences of opinions, such as respondents' willingness to volunteer to help maintain street trees and to contribute money for street trees. This data alone could be useful to any future urban forestry efforts within State College.

An overwhelming majority (91.7\%) of State College residents stated that street trees were of great importance in their community. Less than $1 \%$ responded that street trees were not important in their community. Sixty-one percent of respondents were willing to volunteer some of their time to help maintain street trees planted along the street that they lived on. Thirty-six percent of respondents reported a willingness to contribute money toward a fund to be used solely for the care of street trees in State College.

\section{CONCLUSION}

Care should be taken not to directly transfer findings of this study to other urban locales, as State College's permanent residents may, as mentioned, be highly reflective of a university community. Nonetheless, the technique described in this paper provides a model by which other individuals, organizations, or governmental entities could gauge residential opinions on this and/or comparable topics regarding street trees. The major expenses for implementing such a project is the two-way, first-class postage, stationary/copying costs, and the labor needed for data input and analysis. Although data input and analysis for this project was facilitated by SPSS statistical package, scoring could be done by hand if only frequencies and percentages are desired.

Urban forestry programs face the continuing challenges of higher costs of planting and maintenance combined with increasing difficulty in obtaining funds, often largely from local tax revenues, to accomplish their needed work as we enter a new millennium.

The high level of support for street trees exhibited by respondents to this research study is important information to State College's and other communities' street tree planning and management personnel. Knowledge obtained from this research might be useful in helping to create and/or implement a residential support program to assist in successful planting, maintenance, and fund-raising for increased numbers of street trees.

\section{LITERATURE CITED}

Coley, R.L., F.E. Kuo, and W.C. Sullivan. 1997. Where does community grow? The social context created by nature in urban public housing. Environ. Behav. 294:468-492.

Daily, G.C. (Ed.) 1997. Nature's Service: Societal Dependence on Natural Ecosystems. Island Press, Washington, DC. $392 \mathrm{pp}$.

DeAraujo, M.N. 1994. Urban Tree Attitudes and Comparison of Three Survey Methods in the City of Curitiba, Pr, Brazil. Thesis. Michigan State University, East Lansing, MI.

Fischer, H.W. 1996. The Sociologist's Statistical Tools. University Press of America, Latham, MD. 242 pp.

Hull, B. 1992. How the public values urban forests. J. Arboric. 18(2):98-101.

Schroeder, H., and S. Ruffolo. 1996. Householder evaluations of street trees in a Chicago suburb. J. Arboric. 22(1):35-43.

Smardon, R.C. 1988. Perception and aesthetics of the urban environment: Review of the role of vegetation. Landscape Urban Plann. 15:85-106. 
Sommer, R., H. Guenther, and P. Barker. 1990. Surveying householder response to street trees. Landscape J. 9(2):79-85.

State College Borough Municipal Tree Plan: 1993-1998. 1993. State College, PA.

Summit, J., and E.G. McPherson. 1998. Residential tree planting and care: A study of attitudes and behavior in Sacramento, California. J. Arboric. 24(2):89-96.

Ulrich, R. 1984. View through a window may influence recovery from surgery. Science 224:420-421.

U.S. Department of Commerce, Bureau of the Census, Census of Population and Housing. 1990. Tape file 1A, 1990. Washington, DC.

Voelkl, K., and S. Gerber. 1999. Using SPSS for Windows. Springer, New York, NY. 264 pp.

Acknowledgments. Financial support for this research was provided by the Longwood Foundation, Inc. The work presented here was part of a thesis submitted in partial fulfillment of the requirement for a M.S. degree at the University of Delaware. I would like to thank Alan Sam, Superintendent of Buildings and Grounds, Borough of State College, Pennsylvania, for his valuable assistance.

Consulting Arborist

576 East Third Street

South Boston, MA 02127

balsamea@juno.com

Résumé. Cette recherche visait à découvrir s'il y avait une différence d'opinion à propos de la valeur des arbres de rues parmi les résidants, et ce dépendant si les résidants avaient ou non un arbre planté directement en façade de leur résidence. En réponse à un questionnaire structuré, 676 résidants de State College en Pennsylvanie ont donné leurs opinions sur les bénéfices et les ennuis concernant les arbres de rues. Des recherches démographiques utilisant des statistiques descriptives ont été employées pour lister les caractéristiques de la population cible. Cette recherche a permis découvrir qu'il y avait une différence statistiquement significative dans les opinions des résidants dépendant s'il y avait ou non un arbre de rue planté devant la résidence. Dans le développement des politiques publiques à propos des arbres de rues, il est recommandé que des études similaires soient menées pour mieux comprendre les opinions des résidants sur cette question.

Zusammenfassung. Diese Studie versucht zu bestimmen, ob die generelle Einstellung von Anwohnern zu Strassenbäumen anders ist, wenn sie einen direkt vor ihrem Grundstück haben. In einem strukturierten Fragebogen haben 676 Anwohner des State College in Pennsylvania ihre Meinungen über die Vor- und Nachteile von Strassenbäumen ausgedrückt. Durch beschreibende Statistik wurden die demografischen Ergebnisse über die Charakteristika der Zielpopulation gelistet. Diese Studie zeigt, das es statistisch relevante Unterschiede in den Meinungen gab, wenn die Bäume direkt vor dem Grundstück standen. Bei der Entwicklung von öffentlichen Strategien in Beziehung auf Strassenbäumen wird empfohlen, dass weitere ähnliche Studien durchgeführt werden, um ein besseres Verständnis für die öffentliche Meinung zu diesem Thema zu erhalten.

Resumen. Esta investigación se condujo para determinar si existe una diferencia de opinión sobre el valor de los árboles urbanos entre los residentes dependiendo de si tienen un árbol plantado en frente de su casa. En respuesta a un cuestionario estructurado, 676 residentes de State College, Pennsylvania dieron sus opiniones de los beneficios y molestias de los árboles. Con base en datos demográficos y utilizando estadística descriptiva se enlistaron las características de la población objetivo. Esta investigación mostró que hubo diferencia significativa entre las opiniones de los residentes dependiendo de si el árbol está plantado en frente de su residencia. En el desarrollo de políticas relacionadas con los árboles urbanos se recomienda que se conduzcan futuros estudios similares para un mejor entendimiento de las opiniones de los residentes sobre este tema. 
Table 1. Socio-demographic distribution of State College, Pennsylvania, respondents.

\begin{tabular}{|c|c|c|}
\hline Characteristics & Number $^{2}$ & Percentagey \\
\hline \multicolumn{3}{|l|}{ Gender } \\
\hline Male & 318 & 47.5 \\
\hline Female & 351 & 52.5 \\
\hline Total & 669 & \\
\hline \multicolumn{3}{|l|}{ Age } \\
\hline $19-25$ & 16 & 2.4 \\
\hline $26-35$ & 74 & 11.0 \\
\hline $36-45$ & 126 & 18.7 \\
\hline $46-55$ & 150 & 22.2 \\
\hline $56-65$ & 101 & 15.0 \\
\hline $66-75$ & 116 & 17.2 \\
\hline 76 and over & 92 & 13.6 \\
\hline Total & 675 & \\
\hline \multicolumn{3}{|l|}{ Ownership } \\
\hline Own & 560 & 83.5 \\
\hline Rent & 107 & 15.9 \\
\hline Other & 4 & 0.6 \\
\hline Total & 671 & \\
\hline \multicolumn{3}{|l|}{ Building type } \\
\hline House & 567 & 84.8 \\
\hline Apartment & 66 & 9.9 \\
\hline Condominium & 23 & 3.4 \\
\hline Other & 13 & 1.9 \\
\hline Total & 669 & \\
\hline \multicolumn{3}{|l|}{ Length of occupancy } \\
\hline Less than 1 year & 30 & 4.5 \\
\hline $1-3$ years & 134 & 20.0 \\
\hline $4-10$ years & 149 & 22.3 \\
\hline More than 10 years & 355 & 53.1 \\
\hline Total & 668 & \\
\hline \multicolumn{3}{|l|}{ Education } \\
\hline Grade school & 3 & 0.4 \\
\hline High school & 57 & 8.4 \\
\hline Business/trade school & 40 & 5.9 \\
\hline College degree & 176 & 26.1 \\
\hline Post-graduate & 399 & 59.1 \\
\hline Total & 675 & \\
\hline
\end{tabular}

${ }^{2}$ Some questions were left unanswered on questionnaires; hence, not all totals are equal to 676 .

yNumbers may not add up to $100 \%$ due to rounding.
Table 2. Evaluation of positive features of street trees in State College, Pennsylvania, comparing tree vs. no tree in front of residence (independent samples t-test).

\begin{tabular}{|c|c|c|c|c|}
\hline $\begin{array}{l}\text { Tree planted directly in } \\
\text { front of house }\end{array}$ & Number $^{z}$ & Mean & t-test & $\mathrm{p}^{\mathrm{y}}$ \\
\hline \multicolumn{5}{|l|}{ Give shade } \\
\hline Yes & 567 & 2.50 & 3.105 & $.002^{*}$ \\
\hline No & 106 & 2.18 & & \\
\hline \multicolumn{5}{|l|}{ Pleasing to the eye } \\
\hline Yes & 565 & 2.86 & 2.126 & $.036^{*}$ \\
\hline No & 103 & 2.70 & & \\
\hline \multicolumn{5}{|l|}{ Flowers on tree } \\
\hline Yes & 550 & 1.20 & -4.274 & $.000^{*}$ \\
\hline No & 103 & 1.75 & & \\
\hline \multicolumn{5}{|l|}{ Fall color } \\
\hline Yes & 562 & 2.53 & -0.414 & .679 \\
\hline No & 106 & 2.57 & & \\
\hline \multicolumn{5}{|l|}{ Neighborhood more livable } \\
\hline Yes & 560 & 2.75 & 2.723 & $.007^{*}$ \\
\hline No & 105 & 2.51 & & \\
\hline \multicolumn{5}{|l|}{ Reduce noise } \\
\hline Yes & 548 & 1.93 & 0.378 & .706 \\
\hline No & 102 & 1.89 & & \\
\hline \multicolumn{5}{|l|}{ Cool building in summer } \\
\hline Yes & 559 & 1.90 & 0.483 & .629 \\
\hline No & 104 & 1.85 & & \\
\hline \multicolumn{5}{|l|}{ Increase privacy } \\
\hline Yes 1 & 563 & 1.85 & -0.978 & .328 \\
\hline No & 104 & 1.96 & & \\
\hline \multicolumn{5}{|l|}{ Improve environment } \\
\hline Yes & 560 & 2.73 & 1.474 & .143 \\
\hline No & 105 & 2.61 & & \\
\hline \multicolumn{5}{|l|}{ Attract birds } \\
\hline Yes & 563 & 2.22 & 0.476 & .634 \\
\hline No & 105 & 2.17 & & \\
\hline \multicolumn{5}{|l|}{ Increase property value } \\
\hline Yes & 548 & 2.31 & 3.136 & $.002^{*}$ \\
\hline No & 102 & 2.00 & & \\
\hline
\end{tabular}


Table 3. Evaluation of negative features of street trees in State College, Pennsylvania, comparing tree vs. no tree in front of residence (independent samples t-test).

\begin{tabular}{|c|c|c|c|c|}
\hline $\begin{array}{l}\text { Tree planted directly in } \\
\text { front of house }\end{array}$ & Number $^{2}$ & Mean & t-test & $\mathrm{p}^{\mathrm{y}}$ \\
\hline \multicolumn{5}{|l|}{ Attract animal problems } \\
\hline Yes & 555 & 0.58 & -0.499 & 618 \\
\hline No & 105 & 0.62 & & \\
\hline \multicolumn{5}{|l|}{ Insects/diseases in tree } \\
\hline Yes & 556 & 0.81 & -1.422 & .156 \\
\hline No & 105 & 0.93 & & \\
\hline \multicolumn{5}{|c|}{ Branches break power lines in storms } \\
\hline Yes & 561 & 0.85 & -2.112 & $.037^{*}$ \\
\hline No & 105 & 1.08 & & \\
\hline \multicolumn{5}{|l|}{ Sidewalk damaged } \\
\hline Yes & 565 & 1.23 & 2.506 & $.012^{*}$ \\
\hline No & 105 & 0.95 & & \\
\hline \multicolumn{5}{|l|}{ Branches fall } \\
\hline Yes & 558 & 1.03 & 0.632 & .528 \\
\hline No & 105 & 0.98 & & \\
\hline \multicolumn{5}{|l|}{ Leaves fall } \\
\hline Yes & 558 & 1.22 & 1.178 & .239 \\
\hline No & 105 & 1.10 & & \\
\hline \multicolumn{5}{|l|}{ Flowers/seeds fall } \\
\hline Yes & 555 & 0.99 & 1.163 & .245 \\
\hline No & 102 & 0.87 & & \\
\hline \multicolumn{5}{|l|}{ Block the sun } \\
\hline Yes & 560 & 0.63 & -0.681 & .496 \\
\hline No & 104 & 0.68 & & \\
\hline \multicolumn{5}{|l|}{ Darken street at night } \\
\hline Yes & 557 & 0.60 & -0.342 & .733 \\
\hline No & 105 & 0.63 & & \\
\hline \multicolumn{5}{|l|}{ Cause allergies } \\
\hline Yes & 555 & 0.59 & -1.306 & .192 \\
\hline No & 103 & 0.70 & & \\
\hline \multicolumn{5}{|l|}{ Block visibility } \\
\hline Yes & 556 & 0.48 & -3.209 & $.002^{*}$ \\
\hline No & 105 & 0.77 & & \\
\hline
\end{tabular}


Table 4. Importance of street trees to residents of State College, Pennsylvania.

\begin{tabular}{|c|c|c|c|}
\hline Response & $\begin{array}{l}\text { Tree planted in } \\
\text { front of house }\end{array}$ & $\begin{array}{l}\text { No tree planted in } \\
\text { front of house }\end{array}$ & Total responses \\
\hline \multicolumn{4}{|c|}{ Of great importance } \\
\hline Number & 515 & 91 & 606 \\
\hline Percentage & 92.8 & 85.8 & 91.6 \\
\hline \multicolumn{4}{|c|}{ Of moderate importance } \\
\hline Number & 38 & 12 & 50 \\
\hline Percentage & 6.8 & 11.3 & 7.6 \\
\hline \multicolumn{4}{|l|}{ Not important } \\
\hline Number & 2 & 3 & 5 \\
\hline Percentage & 0.4 & 2.8 & .8 \\
\hline Total number & 555 & 106 & $661^{z}$ \\
\hline Percentage & 100.0 & 100.0 & 100.0 \\
\hline
\end{tabular}

Chi-square $=10.000$

$\mathrm{Df}=2$

Significance $=.007$ (at the .05 level)

${ }^{2}$ Some questions were left unanswered on questionnaires; hence, not all totals are equal to 676.

Table 5. Willingness to volunteer with help maintaining street trees in State College, Pennsylvania.

\begin{tabular}{llll}
\hline Response & $\begin{array}{l}\text { Tree planted in } \\
\text { front of house }\end{array}$ & $\begin{array}{l}\text { No tree planted in } \\
\text { front of house }\end{array}$ & Total responses \\
\hline $\begin{array}{l}\text { Yes } \\
\text { Number }\end{array}$ & 343 & 59 & 402 \\
$\begin{array}{l}\text { Percentage } \\
\text { No }\end{array}$ & 62.3 & 57.8 & 61.6 \\
$\begin{array}{l}\text { Number } \\
\text { Percentage }\end{array}$ & 208 & & \\
& 37.7 & 43 & 251 \\
$\begin{array}{l}\text { Total number } \\
\text { Percentage }\end{array}$ & $\mathbf{5 5 1}$ & 42.2 & 38.4 \\
\hline
\end{tabular}

Chi-square $=.707$

$\mathrm{Df}=1$

Significance $=.401$ (at the .05 level)

"Some questions were left unanswered on questionnaires; hence, not all totals are equal to 676 . 
Table 6. Willingness of State College, Pennsylvania, residents to contribute money to care for street trees.

\begin{tabular}{|c|c|c|c|}
\hline Response & $\begin{array}{l}\text { Tree planted in } \\
\text { front of house }\end{array}$ & $\begin{array}{l}\text { No tree planted in } \\
\text { front of house }\end{array}$ & Total responses \\
\hline \multicolumn{4}{|l|}{ Yes } \\
\hline Number & 203 & 35 & 238 \\
\hline Percentage & 37.0 & 33.3 & 36.4 \\
\hline \multicolumn{4}{|l|}{ No } \\
\hline Number & 254 & 41 & 295 \\
\hline Percentage & 46.4 & 39.0 & 45.2 \\
\hline \multicolumn{4}{|l|}{ No opinion } \\
\hline Number & 91 & 29 & 120 \\
\hline Percentage & 16.6 & 27.6 & 18.4 \\
\hline Total number & 548 & 105 & $653^{z}$ \\
\hline Percentage & 100.0 & 100.0 & 100.0 \\
\hline
\end{tabular}

Chi-square $=7.625$

Df $=1$

Significance $=.054$ (at the .05 level)

zSome questions were left unanswered on questionnaires; hence, not all totals are equal to 676. 